\title{
Substantive and instrumental rationality in public bidding: gains and losses in the selection of the most advantageous bid
}

\author{
VANILSON VIANA CARDOSO ${ }^{1}$ \\ Airton Adelar MUELleR ${ }^{1}$
}

${ }^{1}$ Universidade Regional do Noroeste do Estado do Rio GRANDE do SUl (UNIJUÍ), IJUÍ - RS, BRAZIL

\begin{abstract}
This article aims to identify elements present in the bidding processes of public administration related to instrumental and/or substantive rationality. The results show that the tensions between these two approaches contribute to the critical evaluation of the public manager's decisions on defining the licensing and technical qualification criteria required by the bidding companies. Although the event should promote price competition and provide the best contract, the excess of instrumental rationality in the discretionary and linked acts result in substantial deficiencies for the functioning of the public administration, which goes against the public interest. The study's theoretical foundation is based on the literature about rationality in the organizations and the tensions between the instrumental and substantive rationality. This is a qualitative research, performed through document analysis, bibliographical research, and non-participant observation. Public bidding sessions of a town in the Northwest of the state of Rio Grande do Sul with a population of about 60,000 inhabitants were observed between 2017 and 2019 . The research showed that the government's bidding processes are overly guided by instrumental rationality. This characteristic promotes disputes focused on bidders' private interests at the expense of the public interest, which may trigger a series of problems to the public administration.
\end{abstract}

Keywords: Instrumental and substantive rationality. Public administration. Biddings. Better contract.

\section{Substantive and instrumental rationality in public bidding: gains and losses in the selection of the most advantageous bid}

\section{Resumo}

Este artigo foi desenvolvido com o objetivo de identificar elementos nos processos licitatórios da administração pública, que mantêm relação com a racionalidade instrumental e/ou substantiva. Os resultados apontam que o tensionamento entre essas duas abordagens contribui para a avaliação crítica das decisões do gestor público, no que tange à definição dos critérios de habilitação e qualificação técnica exigidos das empresas licitantes. Ao passo que o certame deveria promover a concorrência de preços e proporcionar a melhor contratação, o excesso de instrumental de que se revestem os atos discricionários e vinculados resulta, com base nos resultados obtidos, em deficiências substanciais para o funcionamento da administração pública, que maculam a supremacia do interesse público. Para a elaboração do estudo, adotou-se como fundamentação teórica um conjunto de precedentes da literatura que discute a racionalidade nas organizações, bem como o processo de tensão entre a abordagem instrumental e a substantiva. Trata-se de pesquisa qualitativa, realizada mediante análise documental, revisão bibliográfica e observação não participante. Entre os anos de 2017 e 2019, acompanharam-se as sessões públicas de licitações de um município do noroeste do Estado do Rio Grande do Sul, com população de cerca de 60 mil habitantes. Em suma, constatou-se que o poder público, ao se pautar demasiadamente pela racionalidade instrumental durante a condução dos processos licitatórios, fomenta uma disputa de interesses particulares dos licitantes, alheios ao interesse público, o que pode desencadear uma série de problemas para a administração pública.

Palavras-chave: Racionalidade instrumental. Racionalidade substantiva. Administração pública. Licitações. Melhor contratação.

Racionalidad sustantiva y racionalidad instrumental en licitaciones públicas: ganancias y pérdidas para la selección de la propuesta más ventajosa

\section{Resumen}

Este artículo fue desarrollado con el objetivo de identificar elementos en los procesos de licitación de la administración pública, que están relacionados con la racionalidad instrumental y/o sustantiva. Los resultados muestran que la tensión entre estos dos enfoques contribuye a la evaluación crítica de las decisiones del gestor público en lo que se refiere a la definición de los criterios de capacidad y calificación técnica exigidos a las empresas licitadoras. Si bien la licitación debería promover la competencia de precios y proporcionar la mejor contratación, el exceso de instrumental que reviste los actos discrecionales y vinculados resulta, de acuerdo con los resultados obtenidos, en deficiencias sustanciales para el funcionamiento de la administración pública que empañan la supremacía del interés público. Para la elaboración del estudio se adoptó como fundamentación teórica un conjunto de precedentes de la literatura que discute la racionalidad en las organizaciones, así como el proceso de tensión entre el enfoque instrumental y el sustantivo. Se trata de una investigación cualitativa, realizada a través de análisis de documentos, revisión bibliográfica y observación no participante. Entre 2017 y 2019, se siguieron las sesiones públicas de licitaciones de un municipio del noroeste del estado de Río Grande do Sul, con una población de alrededor de 60 mil habitantes. En suma, se constató que el poder público, al guiarse excesivamente por la racionalidad instrumental durante la conducción de los procesos licitatorios, fomenta una disputa de intereses privados de los licitadores, ajenos al interés público, lo que puede desencadenar una serie de problemas para la administración pública.

Palabras clave: Racionalidad instrumental. Racionalidad sustantiva. Administración pública. Licitaciones. Mejor contratación. 


\section{INTRODUCTION}

According to Santos and Serva (2013), the majority of Brazilian research to analyze the rationality of organizations is based on the book A nova ciência das organizações: uma reconceituação da riqueza das nações (GUERREIRO RAMOS, 1981), Portuguese for "The new science of organizations: a reconceptualization of the wealth of nations". The resulting understanding places the individual at the center of decision-making in organizations, requiring a minimum of social consensus. Once people in general are constantly faced with the tension between substantive and instrumental rationality, organizational objectives would then fail.

Supported on the original definitions by Guerreiro Ramos (1981), the main model of analysis of substantive and instrumental rationality adopted in this article was developed by Serva (1997) and later embraced by several authors. In 2012 there were at least 17 published works (among dissertations and theses) that adopted, in whole or in part, the categories and dimensions of this model (SANTOS and SERVA, 2013). The studies were developed from market organizations and from the tertiary sector, thus not contemplating the tension of rationalities in public administration. Serva, Caitano, Santos et al. (2015) classify the results of studies on rationality in first generation (group A) and second generation (group B). These are firstly, empirical research carried out to identify the predominant rationality in management, followed by the ones that promote the tension between rationalities and the in-depth analysis of complex relationships.

In public bids, the aim is to choose the best proposal in order to obtain the best contracting by the public administration (BANDEIRA DE MELLO, 2014). The obligation to bid, resulting from the constitutional provision (BRASIL, 1988), is guided by the principles that govern Brazilian administrative law: legality, impersonality, morality, publicity and efficiency. Therefore, the public administrator must make every effort to ensure that the community interests will be protected, and may take advantage of some prerogatives such as the cancellation or revocation of the bid, provided that the act is duly substantiated as in the biddings law (BRASIL, 1993). Although bidding processes have a routine foreseen by law, the public entity may adequate the demands and technical requirements of the bidding companies, according to what had been specifically requested. This margin of action is called discretionary act (MEIRELLES, 2016).

It was in this decision-making opportunity (discretionary margin) that the research intended to analyze the tension between substantive and instrumental rationality. We believe it is appropriate to expand the studies on rationality within public administration, since it is the mechanism through which the government obtains goods and services used in the execution and maintenance of public services in general, whether directly or indirectly (DI PIETRO, 2016).

The research supports the investigations carried out by Santos (2012). The author observed that public entities present, on the one hand, instrumental rational orientation resulting from the expectation of efficiency and, on the other hand, a political orientation guided to public interest, resulting in the tension between the rationalities from the administrative practices adopted by public managers. Although the starting point is the public manager's discretionary margin, this article considered the dynamics between the discretionary act as the core for understanding the tension between rationalities.

The main objective of this article was to analyze the daily routine of public bids; how public managers conduct the decisionmaking processes and what orientation (substantive and/or instrumental) is the one adopted by them. Nevertheless, the study did not only identify the preponderant rationality, but also sought to understand the interrelationships and the dynamics of tension, from the definition of the object to the final decision (result). Here you can classify it as a second-generation scientific work (SERVA, CAITANO, SANTOS et al., 2015). It is also a qualitative research of exploratory level, developed from documental analysis and non-participating observation, besides the pertinent bibliographical review. 


\section{INSTRUMENTAL RATIONALITY AND SUBSTANTIVE RATIONALITY}

Notably, the book A nova ciência das organizações: uma reconceituação da riqueza das nações (GUERREIRO RAMOS, 1981) was a milestone for organizational studies of critical approach in the Brazilian context. Although it is a study based overall on social science, the author questions principles that underlie the economic and the administrative sciences in contemporary times. Through the inquiry of the accepted concepts, either distorted or simply reproduced by modern society, the discussion ponders questions concerning both private and public organizations in general. In this way, "Guerreiro Ramos's critique stood out in the field of organizational studies because it was not only criticism, but also a contribution to the development of a new theoretical conception divergent from traditional theories" (SERVA, CAITANO, SANTOS et al., 2015, p. 417).

Guerreiro Ramos (1981) criticizes modern reasoning, due to his compatibility with the current normative structure, in which distorted language tends to become usual. This hegemony could be counteracted based on human nature's substantive rationality. Unlike the Weberian formal rationality, the proposal aims to broaden the understanding of possible counterpoints to formal logic, even as a regulator of the economic process, since "the market-centered society is only a recent form of ordering human life" (SERVA, 1997, p. 30).

Souza and Ornelas (2015, p. 450) point out that "Alberto Guerreiro Ramos understood organizations as the social institute whose influence is notably decisive in the propagation of the utilitarian logos". This is a counterpoint to the established organizational theory in the sense that adaptation to external factors is not a valid alternative. Thus, while the correlation of the theory of organization is found in formal social science, Guerreiro Ramos (1981, p. 45) infers that "the counterpart of organization's new science is the substantive social science".

In order to sustain the discussion, the Habermasian thinking suggests the predominance of mutual-understanding-oriented processes, in which agreements must be verbal.

[...] While in strategic action one acts on the other to provide the desired continuation of an interaction, in communicative action one is rationally motivated by the other to action and adherence - and this is due to the illocutionary effect of commitment that the offer of an act of speech elicits (HABERMAS, 1989, p. 79).

Two main conceptual definitions emerge from a sociological perspective: instrumental action (deals with the constitution of a systematic world) and communicative action (deals with the world we live).

In spite of the primordial interest of Habermas (1989) in the construction of a critical theory of society, Guerreiro Ramos $(1981$, p. 20) remarks that the author "supports a type of motivational psychology which excludes the role of reason in human psyche". This statement confronts one of the central definitions of substantive rationality, that "reason is the basic concept of any science in society and in organizations" (GUERREIRO RAMOS, 1981, p. 23). In any case, substantive rationality aims to transcend the close relationship reason-calculation, by judging it on an ethical values basis (SERVA, 1997).

In most public organizations the tension between instrumental and substantive rationality (SANTOS and SERVA, 2013) does not necessarily adopt a pattern since their compounding elements are variable. In this sense, "both rationalities are necessary in public management and are based on the ethics of responsibility and conviction" (SANTOS and SERVA, 2013, p. 15). This makes studies on the subject even more complex, varying greatly according to each context, process and decision involving the public manager, since the aspects which guide human conduct simply cannot be forgotten.

Organizational studies that evaluate instrumental and substantive rationalities have identified the predominance of the former, while the nominalization arises precisely from the opposition in adopting purely instrumental models (CERRI, MARANHÃO and PEREIRA, 2017). On the other hand, it does not necessarily mean that the predominance of one rationality implies a reduction in the other (SIQUEIRA, 2017). Among the characteristics identified in these phenomena are "centrality of communication and social relations as a political dimension and arena of tension between rationalities" (SIQUEIRA, 2017, p. 781). The difference lies in the sharing of the decision-making through interpersonal, environmental, and social relationships. 
Ethical, moral, and philosophical differences plus power struggles are issues that also permeate public spaces and therefore contribute to the formation of a purely instrumental orientation. The solution to this situation would be to adopt "a process leading to substantive actions in order to open up increasingly democratic, participatory and dialogic spaces with the aim to balance growing utilitarian approaches in public management to the detriment of the expected social impacts" (SOUSA and PAIVA JUNIOR, 2010, p. 114). By discussing the corrosion of character, Sennett (2009) points out that aspects related to loyalty, trust, mutual help and commitment are essential for developing ways of acting consistent with the human condition. Such issues are not restricted to private companies, but are more visible in public administration, since the manager makes commitments beyond the environment of the organization, for he is in fact a manager of society (GUERREIRO RAMOS, 1983).

Substantive actions and dialogic processes are two complementary approaches (SERVA, 1997) once they defend human emancipation. Thus, communicative action (HABERMAS, 1989) and substantive rationality (GUERREIRO RAMOS, 1981) make up the theoretical basis used in tensioning in face of instrumental rationality. Since it is a study that deserves further investigation and that is currently under development, substantive approach is adopted, for it is contemporary to the Frankfurt School (SERVA, CAITANO, SANTOS et al., 2015).

\section{DISCRETIONARY ACT AND POWERS OF THE PUBLIC MANAGER IN POST-RETIREMENT MANAGEMENT}

Guided by the tension between instrumental and substantive rationality, this study sought to evaluate the share of decisions of the public manager, in view of bidding processes which allow this manager to use some freedom, even if within the limits of the law. Regarding the principles and fundamentals of public administration, discretion derives precisely from such a prerogative of the public administrator (BANDEIRA DE MELLO, 2014). Although this is not a legal investigation, it is important to stress that as a rule, public management is conducted by one of its primary principles: legality.

In the same way that there is no rule for the definition of the competencies inherent to the public manager, important studies (BUZATTO, 2012; REIS and MATOS, 2012; SILVA and ROQUETE, 2013; VALADÃO JÚNIOR, BUZATTO, MEDEIROS et al., 2017) have been developed in order to identify the manager's main weaknesses and then propose actions in order to improve public administration. Although there are legal mechanisms to control acts of public administration, as a rule they are based on an instrumentalist view (HABERMAS, 1989) of resources application and compliance with the principle of administrative efficiency (BRESSER-PEREIRA, 2017). It prevents other precepts, though, such as reasonableness and proportionality from being better evaluated (BANDEIRA DE MELLO, 2014).

A research developed with the purpose of investigating the competences of the public manager (BUZATTO, 2012) points out weaknesses related to political issues, to the promotion of citizenship and democracy, and to the absence of a vision towards sustainable ways. There is, therefore, a need to improve the full capacity of the team involved (SILVA, MOTA, DORNELA, et al., 2017), as well as the use of methodologies that can be practiced with the actors.

The administrative powers of the public manager originate from administration and are diversified according to demands of the public service, of collective interest and from the objectives pursued (MEIRELLES, 2016). Therefore, they are not to be confused with political powers, since "they are true working instruments, suitable for carrying out administrative tasks. Hence the reason they are considered instrumental powers' (MEIRELLES, 2016, p. 137, from the author's remark).

As a result of the freedom to perform acts before the legal system, administrative powers are classified in bound and discretionary (BANDEIRA DE MELLO, 2014). Even so, discretion does not imply broad freedom of action for the public manager, as it only occurs if there is legal provision - unlike arbitrary power. Regarding public interest, when faced with a matter guided by discretion, the public manager must adopt decisions that best suit the interests of public administration, and which benefit the administered community. 
The weaknesses in the competencies of the public manager, as the literature points out, are contemporary to the State's management reform promoted in Brazil in the mid-1990s. In this sense, there is a logic of efficiency of the provisions resulting from public administration activities, which were originated after the inception of the welfare state in the 1940s and are maintained as an attempt to overrun neoliberal opposition (BRESSER-PEREIRA, 2017). Furthermore, "Brazilian management reform continues to thrive, especially at states and large municipalities levels, because it is there that modern management is most needed" (BRESSER-PEREIRA, 2017, p. 152). Among the objectives, a higher efficiency on social services, which is historically the second reform of the modern State, followed by the bureaucratic reform. Although the consumption promoted by public administration (collective) is understood as more efficient than the private one, there are still deficiencies in the supply of products and services for public use.

\section{SELECTING THE BEST BIDDER}

By analyzing the managerial reform of the Brazilian public administration during the two decades that followed its implementation, Bresser-Pereira (2017, p. 154) got to the conclusion that it is embodied in the legitimation and strengthening of the Social State itself: "it implies providing education, health and social security services by collective or public means, turning their consumption collective, rather than individual"

As a result of the consumption increase by governments and in order to keep the administrative structure, public hiring for the execution of public services has also increased. On the other hand, article 37, XXI, of the Federal Constitution (BRAZIL, 1988) made it mandatory to carry out a public bidding for the hiring of works, services, purchase and sales of goods - thus it provides: "except for the specified cases in legislation, works, services, purchases and disposals will be contracted through a public bidding process that ensures equal conditions for all competitors [...]".

Through this administrative procedure, the public administration "selects the most advantageous bid for the contract of its interest, including the ones which promote sustainable economic development" (MEIRELLES, 2016, p. 310).

The acts of the bidding process are, as a rule, binding both for the public administration and for the bidders (organizations participating in the price dispute) (BANDEIRA DE MELLO, 2014; MEIRELLES, 2016). Thus, the noncompliance with the regulatory principles may imply the nullification of the choice, namely: a) formality; b) publicity; c) equality among bidders; d) confidentiality in the submission of bids; e) binding to the public notice or invitation; f) objective judgment; g) compulsory award to the winner; and h) administrative probity (BRASIL, 1993).

Once the bid object has been defined, the public administration is bound to demand in the call for bid (public notice), proof that the participating organizations comply with legal conditions of qualification. The list of documents, certificates and declarations is defined in the Federal Constitution (BRASIL, 1988) and in the Law no. 8,666 (BRASIL, 1993). The same applies when checking the bidders' technical qualification.

In addition to the procedures for legal and technical qualification of organizations, the entire bidding process must promote sustainable national development, as established in article 3 of Law no. 8,666 (BRASIL, 1993), "the bidding process is designed to guarantee the observance of the constitutional principle of isonomy, the selection of the most advantageous proposal for the administration and the promotion of sustainable national development [...]". It is about "invigorating the productive chains of domestic goods and services by the use of government purchasing power" (MEIRELLES, 2016).

On the other hand, due to the complexity of certain bidding objects in the act of contracting services or acquiring goods, the public manager often faces decisions to take, obviously embodied in the guiding principles of bidding and of public administration in general (BANDEIRA DE MELLO, 2014). Such situation normally occurs during the organization of the call for bid, named internal phase of the bidding, once most of the literature understands administration is bound to the rules and conditions of the call for bid made public (SCHEIBLER and FAGANELLO, 2015).

The discretion of the public manager is not to be mistaken with the election of the organization to be hired (PEREIRA JÚNIOR, 2009), as otherwise the real intention of the bidding would be neglected, which is to provide the best contract by securing 
the winning bidder will comply with the obligations assumed. At the same time this margin of decision increases the list of requirements in the contest, if employed wrongly it undermines wide participation. The proposals offer will be reduced, however, not being useful to the public interest and to the pursued objective. As a result, "the infra-constitutional regulations contain a maximum list of requirements which may be asked in order to prove the qualification of bidders" (SCHEIBLER and FAGANELLO, 2015, p. 87).

\section{METHODOLOGY}

Analyzing bidding processes from the ontoepistemological point of view brings us to the field of phenomenology, in face of the need to understand the world in which public agents responsible for conducting the contests live. According to Coltro (2000, p. 44), in such cases one should "consider the pure experience of the subject-researcher, in situations of face-to-face contact with the observed agents", in order to obtain a more forceful observation of the phenomenon under study, as it requires more time for its execution. Although there are at least 6 phenomenological types (BOAVA and MACEDO, 2011), we selected the descriptive phenomenology in this study for it represents the origin of the phenomenological movement; yet, it is reflexive and deals with the evidence obtained from research. Aiming at clarifying alluding issues to the nature of the lived experiences, we analyzed how the tension between instrumental and substantive rationality occurs in the decisions of public managers in face of bidding processes.

As an approach, the research is characterized as qualitative (CHIZZOTTI, 2003), at an exploratory level, since in the context of bidding processes the phenomena of tension between the rationalities present issues that have not yet been elucidated, being equally complex due to interdisciplinary relationships, particularly the body of laws which govern acts of public administration.

For the realization of the empirical study, we accompanied three bidding processes, carried out within the scope of public administration in a municipality in the state of Rio Grande do Sul, through the official publications of the public entity (followed remotely) and during the realization of the bidding sessions (attended in person). The choice of place and nature of the bid object was subject to the most recurrent cases in the sector of public services in the region, as well as the constant unsuccessful bidding and contracting attempts verified throughout the state, according to data released by the Federation of Associations of Municipalities of Rio Grande do Sul (FAMURS) by the end of 2015 (FAMURS, 2015).

Data collection was carried out through documentary, bibliographic and non-participant observation. The documents collected and analyzed comprise reference terms of the subject matter of the bid, call notices, decisions and judgments issued by the public manager in the course of the process, as well as the steps resulting from oppositions and appeals submitted by bidders, in addition to the legislation that guides public purchases nationwide. We examined a total of 3 public bidding processes published between 2015 and 2019, analyzed in full for the same contracting object, which is the temporal delimitation of the study. The literature review encompassed a recap of what was used in the theoretical foundation, plus the analysis and the discussion of results. All remarks were written down during the proposals of public sessions held in the second semester of 2017 and in the first half of 2018 and 2019. Although the permanence of people not involved in the contest is assured by law (for it is a public act), the researchers were not given the right to intervene in the course of the sessions, once they were not from the list of bidders.

Therefore, the investigation could be carried out through non-participant observation activities, with the goal of understanding interventions, discussions and decisions taken by the municipal manager, by public administration technicians and representatives of the bidding organizations. Silva (2007) understands that, in this case, the researcher acts as an interested bystander, aiming to document the maximum number of occurrences which can contribute to the work. Yet, it allows a more accurate description of the symbolic systems identified and to which meaning they are linked to. In order to capture the reactions of the ones involved in the processes during the sessions, a field diary was used - where dialogues and notes related to the categories presented in Box 2 were noted for later analysis in the light of theoretical framework and official documents that guided the contests. 


\section{BIDDING PROCESSES ANALYZED}

Both bidding processes analyzed were developed with the objective of hiring a health services company specialized in managing and operating a 24-hour emergency care unit (aka UPA). The activities included the recruitment and selection of people; acquisition, maintenance, and control of materials; organization of protocols and control of attendance flows, among other actions inherent to health organizations that work without interruption and attend emergency cases.

Until mid-2016, according to federal government standards there was no bidding process regarding UPA's management. For the first contest held back in 2015 the facility worked only for a short period as a municipal health service, and its qualification was not even recognized by the Ministry of Health (MS). There were objections, though; yet, one of the notices was cancelled due to legal non-conformities pointed out by interested organizations, which alleged irregularities and breach of both isonomy and broad competition.

After notes from the control agency, the municipal administration broke the contract for the emergency care unit management by signing an immediate contract in 2017, with the objective of managing the health unit on UPA's proper standards. Then 3 new bidding processes were issued, since the first 2 failed due to the inability of both participating organizations, which did not faithfully comply with the bidding requirements. In this first opportunity, there were 7 proponents, while in the second call this number was reduced to 4 , and finally 3 proponents in the third contest.

\section{ANALYSIS FRAMEWORK}

On the basis of the analysis framework proposed by Serva (1997), which distinguishes the elements of instrumental and substantive rationality, a specific framework was developed for investigations about decisions made by the public manager in the bidding processes analyzed, composed of 5 categories. The organizational processes to cause tension between both rationalities have been replaced by stages of the bidding processes which are adopted by all entities of direct and indirect public administration in Brazil.

Important to say the division employed does not necessarily stem from a doctrinal approach; it rather represents the analyzed phases in a concise way. To complement the study, we used the analysis categories proposed by Santos and Serva (2013), according to Box 1 (it also deals with research conducted from public management.)

Box 1

Tension between substantive and instrumental rationality

\begin{tabular}{|c|c|c|c|}
\hline & $\begin{array}{l}\text { Substantive } \\
\text { Rationality }\end{array}$ & Tension & $\begin{array}{c}\text { Instrumental } \\
\text { Rationality }\end{array}$ \\
\hline $\begin{array}{c}\text { Decision-making Process } \\
\text { Policies and management } \\
\text { practices } \\
\text { Goals and objectives } \\
\text { Effects } \\
\text { Pressures }\end{array}$ & $\begin{array}{c}\text { Authenticity } \\
\text { Autonomy } \\
\text { Authorization } \\
\text { Understanding } \\
\text { Ethical judgment } \\
\text { Social satisfaction }\end{array}$ & \multirow{2}{*}{$\begin{array}{c}\text { Organizational } \\
\text { characteristics } \\
\text { Absence of consensus } \\
\text { Pressure forces and } \\
\text { influences } \\
\text { Inconformity and beliefs } \\
\text { Personal and } \\
\text { organizational } \\
\text { preferences }\end{array}$} & $\begin{array}{c}\text { Calculation } \\
\text { Success and results } \\
\text { Ends } \\
\text { Maximization of resources } \\
\text { Profitability } \\
\text { Utility }\end{array}$ \\
\hline $\begin{array}{l}\text { Values and Objectives Identity } \\
\text { and Standards } \\
\text { Origin, diffusion and sharing } \\
\text { Personal and organizational } \\
\text { objectives } \\
\text { Stimulus and realization }\end{array}$ & $\begin{array}{c}\text { Authenticity } \\
\text { Autonomy } \\
\text { Authorization } \\
\text { Understanding } \\
\text { Ethical judgment } \\
\text { Social satisfaction } \\
\text { Emancipation values }\end{array}$ & & $\begin{array}{c}\text { Performance } \\
\text { Success and results } \\
\text { Ends } \\
\text { Profitability }\end{array}$ \\
\hline
\end{tabular}

Source: Santos and Serva (2013, p. 8). 
According to Box 1 (SANTOS and SERVA, 2013), the resulting tension of the decision-making processes, of values and objectives, makes it possible to reevaluate some of the competencies of the public manager identified as incapacitated in some of the studies (BUZATTO, 2012; REIS and MATOS, 2012). Therefore, it is possible to discuss specific issues involving public administration, especially those that are starting points for the public manager. This is the case with bidding processes, since they hire companies responsible for providing goods and services to governments, which in large part directly impact the quality of public services.

\section{THE CATEGORIES ANALYZED}

Box 2 presents the categories analyzed and their constituent elements, for both rationalities: substantive and instrumental. The first one allows us to verify that the dynamics existing between both rationalities must be considered as the object of study, once it results from regulatory principles of public administration acts, such as: the obligation to bid, efficiency and impersonality.

Box 2

Categories and dimensions of substantive and instrumental rationalities in the bidding processes analyzed

\begin{tabular}{|c|c|c|}
\hline Category & Substantive Rationality & Instrumental Rationality \\
\hline Origin and definition of the bid object & Collective interest & Legal ordinance \\
\hline Definition of qualification requirements & Understanding & Logic deduction \\
\hline Trial for challenges and appeals & Plurality of proposals & Risk elimination, calculating action \\
\hline $\begin{array}{c}\text { Position of bidding companies } \\
\text { during the session }\end{array}$ & $\begin{array}{c}\text { Bid evaluation and } \\
\text { price dispute }\end{array}$ & Elimination of Competitors \\
\hline Result of the process & Public interest & Private interest/market \\
\hline
\end{tabular}

Source: Elaborated by the authors.

The category origin and definition of the object represents the elements whose public manager initiatives are based in the definition of the bid object. Although the obligation to bid is crucial to public entities, it is not necessarily the result of a legal determination. In contrast, substantive orientation of public administration would result in decisions stemming from the collective interest, which is different from mere compliance with a determination of the control bodies, under penalty of personal responsibility of the manager, in the event of non-compliance with the constitutional determination to bid.

In the case analyzed, it was found that the municipality had a physical infrastructure built with federal resources. Since it was not being used to provide the services for which it was first intended, it was necessary the interference of the Public Federal Ministry (MPF) among other external control bodies. Thus, there was a useful decision-making process (SANTOS and SERVA, 2013) guided by values and final objectives, which do not necessarily represent the search for improvements in the service network and the quality of life of the beneficiary population.

In addition to the legal provisions that establish the definition of qualification requirements for the participating bidders, in both processes analyzed the public administration alternated requirements that do not demonstrate usefulness to the public interest, especially when it comes to obtaining the best contract. In this regard, the public notices required certification and prior registration of the bidders in different regulatory agencies; it proved, however, ineffective in view of the object to be hired. An example is the requirement to register with the National Registry of Health Establishments (CNES), since the activities contracted would be performed in a health unit different from those that the bidding company could have in activity; in other words, without effectiveness in face of the bid object. This criterion was one of the reasons for the failure of the contests, due to the non-qualification of at least two of the participating companies.

In contrast, the entity could establish that the winner should immediately be in charge of the public unit managed in order to assign, for this purpose, the list of health professionals necessary for the execution of the contracted activities. Due to the 
tension between both rationalities, we observe there is an interesting phenomenon in this category, since personal convictions and preferences took over the process, preventing a more substantive evaluation of the issue in the sense of ethical judgment and understanding. Logical deduction is what best describes the decision of the public manager; this view undermines the assessment based on autonomy and collective emancipation (GUERREIRO RAMOS, 1981).

As Campos and Costa (2017) had already suggested, the implementation of social control in bidding processes, based on the dimensions of collective interest and on legal assumptions of public acquisition, would have an integrating and emancipatory function. In this sense, there would be a better allocation of public resources. As mentioned by the authors, improvements in the perceptions of public managers are crucial for the construction of inclusion spaces, avoiding the inception of bidding processes merely as a legal duty of the public administration, but as a stage of local planning.

The risk is that the events have in their origin distortions in order to deliberately prioritize market interests, given the low level of understanding of the actors involved and, above all, to the absence of previous participatory deliberation. (PAZOS, OLAYA and ARIAS, 2017). The problem is intensified if strategies from supplier groups are not identified, which induce the public manager to adopt contradictory criteria in relation to the best public procurement.

We observed that, even though the effects of obtaining the best contract had not been analyzed yet, such a requirement had always been adopted, including by other entities. Logical deduction assumes that, by requiring registration of bidders in different agencies, public administration would be giving a greater safety margin to the management. It is the result of the aspiration for success and from the market orientation, as referred by the first-generation studies of Serva, Caitano, Santos et al. (2015).

In view of the qualification requirements for the bidding companies as previously defined in public notices, there were challenges and appeals resulting from the decisions taken by the public administration authority in the bidding sessions. The trial for challenges and appeals led, respectively, to the suspension and republication of notices from two contests and the defection of proposals of the second contest, when the session was held. Only with the third event was then possible to get the approval of proposals. However, they presented technical disabilities due to non-compliance with requirements defined at the discretion of the public manager.

This sequence of events resulted in contradictions from one public notice to the next. While some requirements were abolished, others were added, contributing to the reduction in the number of contenders. Consequently, delay arose around the hiring of the company that would be responsible for the management of the health unit in the medium term. In other words, while the entity analyzed and judged the challenges and resources presented by the companies, it was extended the start of activities to expand public health services provided to the population. In addition, MPF (federal prosecutors) questioned once again why the issue was not solved and demanded agility from the public manager.

In view of this, requirements based on rational instrumental action became an obstacle so that public administration validated bids which did not meet the requirements based on discretion, restricting the number of offers and consequently the chances of getting the best hire. Pressure from external control agencies was reflected in the fear of violations by the manager in face of decisions taken. Even though public interest might have been prejudiced, such a finding could only be evidenced through ethical judgment. Due to its low level of subjectivity, it was simply ignored in the process.

Although we identified tensions between both rationalities, what prevails in this category is the attempt to eliminate risks. Such risks are not necessarily related to the execution of the services hired by the public administration, but result from the manager's fear of personal responsibility in the event there has been a violation of the principles of legality, impersonality and binding to the notice call. It is a conduct associated with individuality, of a calculating nature, which is reflected in the actions of the subjects (SANTOS and SERVA, 2013).

The procedure for public bids varies according to the adopted modality. In the case studied, both contests were face-to-face where the disputes among suppliers occur through the presentation of an initial offer (bid), followed by bids (BANDEIRA DE MELLO, 2014). Therefore, the category called position of bidding companies during the session was defined as a result of a phenomenon identified during the sessions. It deals with the rivalry between one competitor and another, in which irregular 
documents can jeopardize a good offer price. In none of the analyzed processes did the price involution result from successive bids, which is somehow the main objective of the bidding - to provide the best contracting for the public administration, both in technical and financial terms (BANDEIRA DE MELLO, 2014; MEIRELLES, 2016).

The study conducted by Reis and Cabral $(2018$, p. 107) corroborates this discussion. He points out that even in electronic bidding, where there are more competitors and subsequently lower prices, "there is no significant relationship between the intensification of competition among participants and the effectiveness in delivery. This reinforces the prevalence of a competitive position among companies, to the detriment of public interest and to the best contracting, since there are other performance variables to consider such as feasibility of prices and the delivery capability of the winning bidder (technical qualification).

The typical market rivalry, in which organizations strive for survival at all costs to eliminate potential competitors was pretty much present in the manifestations of both proponents. Although no objection can be raised to such behavior, for the purposes of this study it is important to highlight a likelihood in the relationship between this phenomenon and the initial stages of analysis, confirming in this case that the tension between substantive and instrumental rationalities unfolds both in benefits and in damages to the public administration interests and the community in general. However, there are conditions to cause this result, in special the understanding and the autonomy (HABERMAS, 1989). Offer bids were hampered by the diversity of interpretations resulting from requirements not quite understood by the public entity but included in both public notices. According to Serva (1997, p. 28), "actions towards understanding have proved indispensable to set the tone for substantive reason in tough processes. On average, the sessions lasted about 3 hours, and at the end, an understanding was not reached in order to please the collective interest.

The fifth category was named the result of the process. It was defined this way because it succinctly represents the predominance of market orientations around processes which involved decision-making by the public manager, throughout the development of bidding process. In this sense, Tenório (2008) draws our attention to the likely predominance of typical market strategies in the activities promoted by organizations from the tertiary sector, which would also encompass public management. This phenomenon was evident in the study in question, since there was no guarantee that the public administration obtained the best contract, and therefore that the challenges and desires of social order had in fact been met.

It cannot be said, however, that the instrumental aspect in public offices results only from the pressures of the first sector, but that the management of conflicts between individual ethical issues and organizational survival (GUERREIRO RAMOS, 1981) are mediated in negotiations between the public manager and suppliers, by observing the limits of administrative discretion. Prerogatives of Brazilian public administration defined in the legal system must be better analyzed, though. This demands however, that organizational studies of public spaces advance further (TENÓRIO, 2013).

\section{TENSIONING IDENTIFIED IN BIDDING PROCESSES}

It is worth elucidating that the bidding processes are nurtured from public demand, followed by the decision of the public manager, the notice call, the contest and the definition of the winning company which will execute the service contract or supply of goods and equipment (BANDEIRA DE MELLO, 2014). Within this context, we will analyze the tension between substantive and instrumental rationalities in this item, taking into account the whole bidding process.

Based on the analysis of the 5 categories formulated in this study, we extract the main elements that characterize the tension between the rationalities during the bidding processes. As illustrated in Figure 1, the greater the presence of such elements in the decisions of the public manager, the closer the instrumental approach is. In this way, the margin of discretion allows both substantive and instrumental competences to be developed; this fact can significantly change between one public entity and another. 
Figure 1

Dynamics of tension between substantive and instrumental rationality in the analyzed public bidding processes

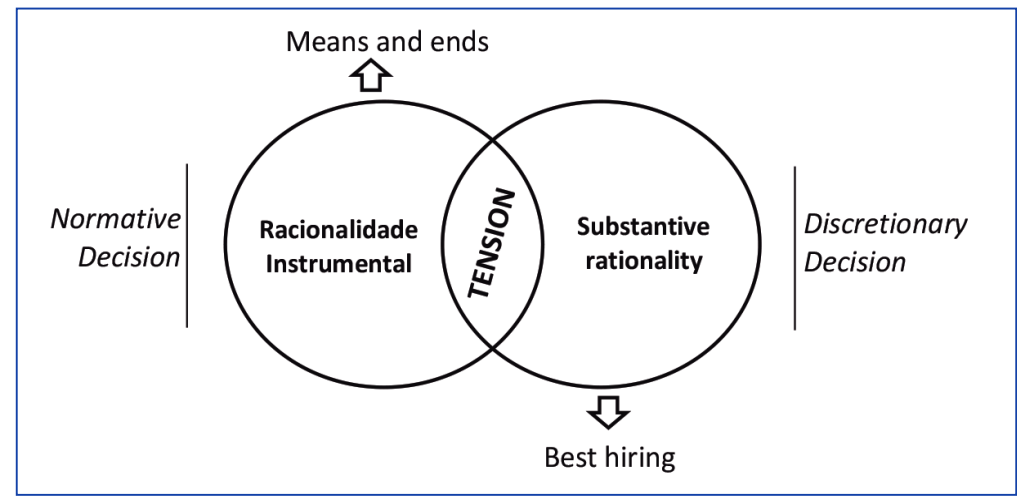

Source: Elaborated by the authors.

This confirms what was also identified by Santos and Serva (2013, p. 15): "in the practice of managers [...] both rationalities are necessary in public management and are backed up by the ethics of responsibility and conviction". It is still to be analyzed under each context, whether this predominance or the appearance of instrumental rationality is or not related to some of the main obstacles to the improvement of public management, and in which situations they can be identified and examined.

To the extent that the public manager decisions no longer take advantage of the discretionary margin and follow normative guidance or remain tied to means and ends (even if discretionary), the tension between both rationalities becomes impaired and instrumental logic prevails. In this way, legal obligations cannot be interpreted as an obstacle to the goal of a better hiring, simply because this fact alone would be enough for the public administration to be bureaucratic. The reform undertaken in the mid-1990s remains under development (BRESSER-PEREIRA, 2017) and studies such as this show that organizational space is one of the arenas of emancipation, especially when it deliberates on issues that have the potential to address the main problems, either social or infrastructure, which influence the overall development of the nation.

\section{FINAL CONSIDERATIONS}

The study made it possible to expand the investigations on rationalities in organizations, analyzing in this opportunity the tension between substantive and instrumental rationality in the decision-making processes during the main stages of public bids. The results indicate that, although the public manager must follow a list of legal determinations, there are prerogatives allowing the manager to act in a discretionary manner and always in defense of the public interest, under the limits of the judicial system. It can also be inferred that the nucleus of tensioning of instrumental and substantive rationality lies in the legaldiscretionary dynamics adopted by public administration. Therefore, both acts strictly guided by the legal limit (linked to each other) and those of discretionary margin can be embodied in the instrumental perspective. In both cases, the administrative prerogative is not always used in a conscious and emancipatory manner, with the potential to avoid the dichotomies arising from instrumental rationality, since they require skills that are impaired by the (misunderstood) logic of efficiency and well defined provisions.

The aim is to identify what is the prearranged goal of a market-centered society, in the case of public procurement, which may represent an important advance in the understanding of emerging barriers whenever substantive rationality is seen in administrative practice. Based on the legal enforceability to bid, defined by the Federal Constitution (BRASIL, 1988), public bids do not avoid debating 2 possible decisions: a) delaying the conclusion of the purchase process; or b) expediting to the end of the purchase process. Such situations confirm the need for a free reality experience and the precise articulation of substantive rationality, at the risk of misunderstanding, as defended by Guerreiro Ramos (1981). Possibly, this constitutes the greatest contribution of the study undertaken. 
Brazilian public administration has undertaken a substantial reform since the 1990s; however, the potential to promote adjustments in order to improve public services is not only about efficiency, but also about rethinking the term from an organizational point of view. It is understood that this article achieved its objectives, since the observed tension between rationalities revealed interesting phenomena, which denote the fragility of bidding processes regarding the position adopted by the public manager. There is a certain omission and/or tacit acceptance of market pressures, which end up hindering the main purpose of bidding - the choice of the best contract.

Once the research was framed as exploratory and in order to keep this debate, we understand that studies on rationality embodied in decisions within public management should advance. For the sake of legality, public managers have certain limitations when it comes to decision-making. Research such as this make it possible to understand imperceptible phenomena through other investigation methods, in which the tension between substantive and instrumental rationalities is not promoted. In this study, a valid starting point can be identified and proposed in order to understand the tension between rationalities in public bids, being its core the legal-discretionary dynamics.

This research presented as a limitation the scope of only one public procurement, although the procedure has been extended for more than 3 years. However, epistemologically, events to confirm the relevance of rationality studies on public management were identified (SERVA, CAITANO, SANTOS et al., 2015) as well as the resulting gains for the managers actions, especially the possibility of proposing new categories of analysis. 


\section{REFERENCES}

BANDEIRA DE MELLO, C. A. Curso de direito administrativo. 30. ed. São Paulo: Malheiros, 2014.

BOAVA, L. T.; MACEDO, F. M. F. Contribuições da fenomenologia para os estudos organizacionais. Cadernos EBAPE.BR, Rio de Janeiro, v. 9, n. esp., p. 470-487, 2011.

BRASIL. Constituição (1988). Constituição da República Federativa do Brasil. Brasília, DF: Senado, 1988.

BRASIL. Lei n. 8.666, de 21 de junho de 1993. Regulamenta o art. 37, inciso XXI, da Constituição Federal, institui normas para licitações e contratos da Administração Pública e dá outras providências. Diário Oficial da União, Brasília, DF, 22 jun. 1993, Seção 1.

BRESSER-PEREIRA, L. C. Reforma gerencial e legitimação do estado social. Revista de Administração Pública, Rio de Janeiro, v. 51, n. 1, p. 147-156, 2017.

BUZATTO, T. R. E. Competências do gestor público: a relação entre a academia e as práticas. 2012. 159 f. Master Thesis (Master Degree in Administration) - Universidade Federal de Uberlândia, Uberlândia, 2012.

CAMPOS, C. V.; COSTA, F. M. Determinantes para o cumprimento de prazo e preço em obras da educação: uma análise nos municípios capixabas. Revista de Administração Pública, Rio de Janeiro, v. 51, n. 5, p. 879-896, 2017.

CERRI, L. T.; MARANHÃO, C. M. S. A.; PEREIRA, J. J. As racionalidades substantiva e instrumental na prática organizacional: um olhar sobre Guerreiro Ramos e os estudos organizacionais. Revista Foco, v. 10, n. 2, p. 125-147, 2017.

CHIZZOTTI, A. Pesquisa em ciências humanas e sociais. São Paulo: Cortez, 2003.

COLTRO, A. A fenomenologia: um enfoque metodológico para além da modernidade. Caderno de Pesquisas em Administração, v. 1, n. 11, p. 37-45, 2000.

DI PIETRO, M. S. Z. Direito administrativo. 29. ed. Rio de Janeiro: Forense, 2016.

FEDERAÇÃO DAS ASSOCIAÇÕES DE MUNICÍPIOS DO RIO GRANDE DO SUL - FAMURS. Chega a 17 número de UPAs fechadas no RS por falta de recursos. Oct. 26, 2015. Available at: <http://www.famurs. com.br/noticias/chega-a-17-numero-de-upas-fechadas-no-rs-porfalta-de-recursos>. Accessed on: May 01, 2019.

GUERREIRO RAMOS, A. A nova ciência das organizações: uma reconceituação da riqueza das nações. Rio de Janeiro: Ed. FGV, 1981.

GUERREIRO RAMOS, A. Administração e contexto brasileiro: esboço de uma teoria geral da administração. Rio de Janeiro: Ed. FGV, 1983.

HABERMAS, J. Consciência moral e agir comunicativo. Rio de Janeiro: Tempo Brasileiro, 1989.

MEIRELLES, H. L. Direito administrativo brasileiro. 42. ed. São Paulo: Malheiros, 2016.

PAZOS, L. S.; OLAYA, A. P. G.; ARIAS, L. F. S. Estrategias de apropiación y desviación de recursos en el Sistema Municipal de Planeación de Santiago de Cali. Revista de Administração Pública, Rio de Janeiro, v. 51, n. 6, p. 1023-1040, 2017.
PEREIRA JÚNIOR, J. T. Comentários à lei das licitações e contratações da administração pública. 8. ed. Rio de Janeiro: Renovar, 2009.

REIS, P. R. C.; CABRAL, S. Para além dos preços contratados: fatores determinantes da celeridade nas entregas de compras públicas eletrônicas. Revista de Administração Pública, Rio de Janeiro, v. 52, n. 1, p. 107-125, 2018.

REIS, R. C. S.; MATOS, C. R. N. Perfil do gestor público: elementos para formação e mudanças. In: CONFERÊNCIA INTERNACIONAL DE ESTRATÉGIA EM GESTÃO, EDUCAÇÃO E SISTEMAS DE INFORMAÇÃO, 1., 2012, Goiânia. Anais... Goiânia: Universidade Estadual de Goiás, 2012.

SANTOS, L. S. A tensão entre a racionalidade substantiva e a racionalidade instrumental na gestão pública: novos caminhos de um campo de estudos. 2012. 262 f. Master Thesis (Master Degree in Administration) - Universidade Federal de Santa Catarina, Florianópolis, 2012.

SANTOS, L. S.; SERVA, M. A tensão entre a racionalidade substantiva e a racionalidade instrumental na gestão pública: novos caminhos de um campo de estudo. In: ENCONTRO DA ANPAD, 37., 2013. Rio de Janeiro. Anais... Rio de Janeiro: Anpad, 2013.

SCHEIBLER, J. L.; FAGANELLO, M. R. Direcionamento de licitações pela administração pública e mecanismos de controle da discricionariedade. FADERGS, v. 7, n. 2, p. 79-114, 2015.

SENNETT, R. A corrosão do caráter: as consequências pessoais do trabalho no novo capitalismo. 14. ed. Rio de Janeiro: Record, 2009.

SERVA, M. A racionalidade substantiva demonstrada na prática administrativa. Revista de Administração de Empresas, v. 37, n. 2, p. 18-30, 1997.

SERVA, M. et al. A análise da racionalidade nas organizações: um balanço do desenvolvimento de um campo de estudos no Brasil. Cadernos EBAPE.BR, Rio de Janeiro, v. 13, n. 3, 2015.

SILVA, A. B. A fenomenologia como método de pesquisa em estudos organizacionais. In: GODOI, C. K.; BANDEIRA-DE-MELO, R.; SILVA, A. B. (Org.). Pesquisa qualitativa em estudos organizacionais: paradigmas, estratégias e métodos. São Paulo: Saraiva, 2007. v. 1, p. 277-307.

SILVA A. G. F.; MOTA, L. A.; DORNELA, C. S. M; LACERDA, A. V. A relação entre Estado e políticas públicas: uma análise teórica sobre o caso brasileiros. Revista Debates, v. 11, n. 1, p. 25-42, Jan./Apr. 2017.

SILVA, Y. C.; ROQUETE, F. F. Competências do gestor em serviços de saúde: análise da produção científica, no período de 2001 a 2011. Revista de Administração em Saúde, v. 15, n. 58, p. 7-114, 2013.

SIQUEIRA, G. M. V. Tensão entre as racionalidades substantiva e instrumental: estudo de caso em uma ecovila no sul da Bahia. Cadernos EBAPE.BR, Rio de Janeiro, v. 15, n. 4, p. 768-782, 2017.

SOUSA, J.; PAIVA JUNIOR, F. G. Os novos tempos e a administração pública: as amarras da racionalidade instrumental e da regulação social. Revista Gestão Pública: Práticas e Desafios, v. 1, n. 1, p. 99-118, 2010. 
SOUZA, C. S.; ORNELAS, A. L. Alberto Guerreiro Ramos e a autonomia dos estudos organizacionais críticos brasileiros: escorços de uma trajetória intelectual. Cadernos EBAPE.BR, Rio de Janeiro, v. 13, n. 3, p. 438-461, 2015.

TENÓRIO, F. G. Um espectro ronda o terceiro setor: o espectro do mercado. 3. ed. Ijuí, RS: Unijuí, 2008.
TENÓRIO, F. G. O pensamento organizacional sob o olhar de Janus. ljuí, RS: Unijuí, 2013.

VALADÃO JÚNIOR, V. M. et al. Formação de competências do gestor público. Revista Capital Científico, v. 15, n. 1, 2017. Available at: <https://revistas.unicentro.br/index.php/capitalcientifico/article/ view/4310/3359>. Accessed on: Mar. 30, 2020.

Vanilson Viana Cardoso

ORCID: https://orcid.org/0000-0003-2006-9227

Ph.D. student in Regional Development at the Regional University of the Northwest of the State of Rio Grande do Sul (UNIJUÍ) in the Stricto Sensu Graduate Program in Regional Development; Master in Regional Development (PPGDR/UNIJUÍ); Lawyer and Administrator, Ijuí - RS, Brazil. E-mail: vanilson-cardoso@hotmail.com

Airton Adelar Mueller

ORCID: https://orcid.org/0000-0001-6270-5856

Ph.D. in Sociology from the Freie Universität Berlin, Germany; Professor in the Postgraduate Program, Master and Doctorate in Regional Development at the Regional University of the Northwest of the State of Rio Grande do Sul (PPGDR/UNIJUí), Ijuí- RS, Brazil. E-mail: airton.mueller@unijui.edu.br 